\title{
Antinociceptive and anti-inflammatory effect of Agaricus blazei Murill in rats submitted to the modified formalin test*
}

\author{
Efeito antinociceptivo e anti-inflamatório do Agaricus blazei Murill em ratos submetidos \\ ao teste da formalina modificado
}

\author{
Claudemir de Carvalho ${ }^{1}$, Nathália Cardoso Alves², Aline Couto Monteiro², Naira Correia Cusma Pelógia ${ }^{3}$ \\ *Received from the Pharmacy Course, University of Pindamonhangaba (FAPI), Pindamonhangaba, SP, Brazil.
}

\section{SUMMARY}

BACKGROUND AND OBJECTIVES: The consumption of mushrooms in popular and traditional medicine is associated to immune modulating activity. It is known that decreasing the inflammatory process will decrease nociception. This study aimed at checking the antinociceptive and anti-inflammatory activity of Agaricus blazei Murill, mushroom of the sun, in Wistar rats using the modified formalin test.

METHOD: Animals $(n=18)$ were distributed in the following groups: Control Group (CG): non-treated animals receiving just 2\% Tween solvent $(n=6)$; Treated Group (TG): animals daily treated orally with $2.65 \mathrm{mg}$ of A. blazei powder in 2\% Tween solvent for 15 days (n $=12$ ). After treatment, they were submitted to the modified formalin test.

RESULTS: After formalin injection, the three phases of the formalin test were observed in CG and TG animals. The treatment with A. blazei has not interfered with formalin test phases I or II, but has decreased the number of paw elevations in phase III.

CONCLUSION: The treatment with Agaricus blazei during 15 days had action in nociceptive response and acute inflammation because rats treated with Agaricus had a lower number of paw movements during phase III,

1. Professor of Biology, Genetics and Embryology, University of Pindamonhangaba (FAPI). Veterinarian. Pindamonhangaba, SP, Brazil.

2. Graduated in Pharmacy, University of Pindamonhangaba (FAPI). Pindamonhangaba, SP, Brazil.

3. Assistant Professor, Doctor in Physiology, University of Taubaté (UNITAU). Pharmacist. Taubaté, SP, Brazil.

Correspondence to:

Naira Correia Cusma Pelógia, MD

Rua Ipanema, 100. Sapé I

12294-015 Caçapava, SP.

E-mail: cusmapelogia@gmail.com which is related to pain caused by mediators of the acute inflammatory process phase.

Keywords: Analgesics, Formalin test, Pain, Pain measurement, Rat.

\section{RESUMO}

JUSTIFICATIVA E OBJETIVOS: O consumo de cogumelos em medicina popular e tradicional está associado à atividade imunomoduladora. Sabe-se que a redução do processo inflamatório reduz a nocicepção. O objetivo deste trabalho foi o de verificar a atividade antinociceptiva e anti-inflamatória do Agaricus blazei Murill, cogumelo do sol, em ratos Wistar, pelo teste da formalina modificado.

MÉTODO: Os animais $(\mathrm{n}=18)$ foram divididos nos seguintes grupos: Grupo Controle (GC): animais não tratados que receberam apenas solvente Tween a $2 \%$ $(\mathrm{n}=6)$; Grupo Tratado (GT): animais tratados diariamente, por via oral, com 2,65 mg de pó de A. blazei em solvente Tween a $2 \%$, durante 15 dias $(\mathrm{n}=12)$. Após o tratamento, foram submetidos ao teste da formalina modificado.

RESULTADOS: Após a injeção da formalina, observaram-se as três fases do teste da formalina nos animais do GC e do GT. O tratamento com A. blazei não interferiu com a fase I ou II do teste da formalina, mas reduziu o número das elevações de pata na fase III.

CONCLUSÃO: O tratamento com A. blazei durante 15 dias teve ação na resposta nociceptiva e na inflamação aguda, pois os ratos tratados com Agaricus realizaram um número menor de movimentações da pata durante a fase III que está relacionada à dor provocada pelos mediadores da fase aguda do processo inflamatório.

Descritores: Analgésicos, Dor, Medição da dor, Rato, Teste da formalina. 


\section{INTRODUCTION}

Mushrooms have been used for thousands of years to produce fermented food and beverages. For centuries, the Asians attribute curative activities to mushrooms in general, stressing their anti-cancer action ${ }^{1}$. It is a nutritive and natural food supplement, important to the daily maintenance of health ${ }^{2}$. In general, the popular medicinal use of mushrooms aims at improving quality of life by decreasing susceptibility to infections and other negative effects caused by a debilitated immune system ${ }^{1}$.

The mushroom of the sun (Agaricus blazei Murrill), native from the Brazilian Southeastern region, appeared during the 1960s as the result of a merge of several fungi native from the Atlantic Forest Mountains of the State of São Paulo. It is different from other mushrooms because it develops under the incidence of strong sunrays, absorbing soil and also sun's nutrients, as opposed to others which prefer wet and shady environments to grow. It is rich in proteins, vitamins, mineral salts and numerous active principles ${ }^{1}$. It has several polysaccharides, one of them, Beta-Glucan, able to inhibit tumor growth ${ }^{4}$

Among its effects described in the literature there is the strengthening of the immune system. This mushroom has preventive (protective) medicinal properties, may act as a powerful coadjuvant in the treatment of hepatitis $\mathrm{C}$, improving the appetite of patients who tend to loose lots of weight during treatment. It has been observed that it decreases side effects of anti-viral drugs, such as fatigue and muscle pain. It has also been confirmed that it is source of proteins and vitamins, since approximately $100 \mathrm{~g}$ of dehydrated mushrooms have $36 \mathrm{~g}$ proteins, as well as iron, phosphorus, calcium and B complex vitamins ${ }^{1}$. However, there are few studies on its pharmacological properties. For this reason, this study aimed at observing the anti-inflammatory and anti-nociceptive action of the mushroom of the sun in Wistar rats.

\section{METHOD}

After the Ethics Committee for Animal Experiments (CEEA), University of Pindamonhangaba (FAPI) approval, protocol $015 / 2010$, this study was carried out in the FAPI vivarium, using male Wistar rats with the same birth date and weighing approximately $450 \mathrm{~g}$.

The protocol was commercially acquired in pharmacy, in the form of capsules with $300 \mathrm{mg}$ of powdered A. bla$z e i$, with the following characteristics: scientific name:
Agaricus blazei Murril; family: Agaricaceae; natural occurrence: Atlantic Forest of the Brazilian Southeastern region; application: therapeutic food supplement. Dehydrated components of capsules presented: 7.5\% humidity; $36.7 \%$ protein; $3.4 \%$ fat; $6.8 \%$ fibers and $7.3 \%$ ashes; $38.3 \%$ sugars; 30 to $60 \mathrm{mg} / \mathrm{g}$ beta-glucan; $939 \mathrm{mg} / 100 \mathrm{mg}$ phosphorus; $18.2 \mathrm{mg} / 100 \mathrm{~g}$ iron; 41.6 $\mathrm{mg} / 100 \mathrm{~g}$ calcium; $0.48 \mathrm{mg} / 100 \mathrm{~g}$ vitamin $\mathrm{B} 1 ; 2.84$ $\mathrm{mg} / 100 \mathrm{~g}$ vitamin $\mathrm{B} 2 ; 354 \mathrm{mg} / 100 \mathrm{~g}$ vitamin D and 40.9 $\mathrm{mg} / 100 \mathrm{~g}$ niacin.

All animals remained for seven days in the experimentation site before beginning the study. Animals $(n=18)$ were distributed in the following groups: Control Group (CG): non-treated animals receiving $2 \%$ Tween solvent only $(\mathrm{n}=6)$; Treated Group (TG): animals daily and orally treated with $2.65 \mathrm{mg}$ of powdered A. blazei in $2 \%$ Tween solvent for 15 days $(\mathrm{n}=12)$. This dose was calculated as from the equivalence with the $300 \mathrm{mg}$ daily $A$. blazei dose for a man weighing $70 \mathrm{~kg}$, according to manufacturer's information. Six animals were maintained per cage, aiming at avoiding stress and overcrowding. During this period, room temperature was maintained at 24 $\pm 2^{\circ} \mathrm{C}$, light/dark regimen alternating every 12 hours, and allowing ad libitum ingestion of feed and water.

After the treatment period, animals were submitted to the formalin test. Pain was induced by administering $50 \mu \mathrm{L}$ of $2.5 \%$ formalin solution in the dorsal region of the left hind paw. Before administration, animals were placed in a transparent observation chamber for 5 minutes to recognize and adapt to the site. Then they were removed for drug administration and replaced in the observation chamber. A mirror was placed behind the chamber to help observations of paw elevation when animal's paw was not visible to the observer.

All paw elevations not related to gait were considered, regardless of the time during which it remained raised. Elevations were continuously counted for 60 minutes and partial elevation numbers were recorded every 5 minutes. The test was divided in three phases: phase I, during the first five minutes; phase II, between the sixth and $20^{\text {th }}$ minute; phase III, from $21^{\text {st }}$ to $60^{\text {th }}$ minute. Phase I evaluated response to nociceptive stimulation; phase II, the inhibitory pain descending pathway and phase III the influence of the inflammatory response on painful response. Test was performed in the right paw of all animals of both experimental groups.

Variance Analysis (ANOVA) for independent samples, followed by the Bonferroni test to detect differences between groups were used to analyze results. Significance level was $5 \%(\mathrm{p}<0.05)$. 


\section{RESULTS}

After formalin injection, the three phases of the formalin test were observed in CG and TG animals (Graph 1). Treatment with $A$. blazei has not interfered with phase I or II of the formalin test, but has decreased the number of paw elevations in phase III (Graph 2).

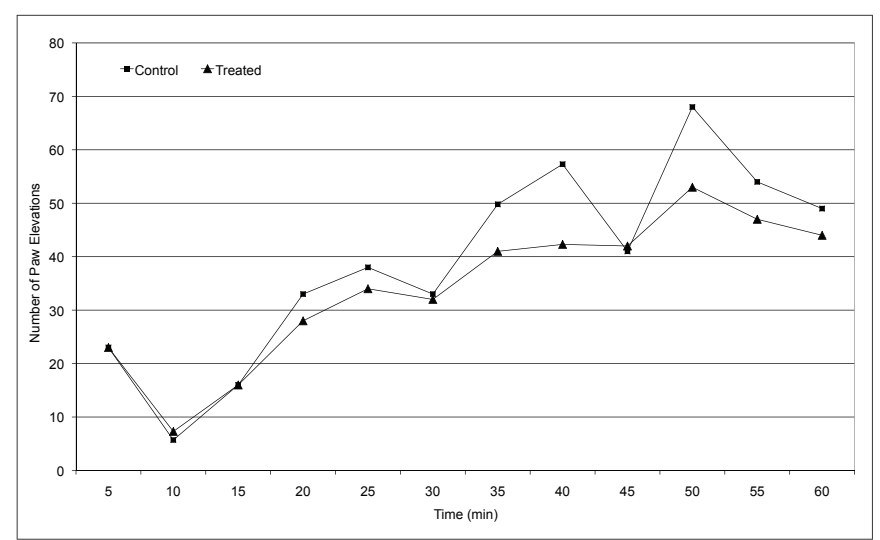

Graph 1 - Right paw elevations of male Wistar rats submitted to the modified formalin test.

$\mathrm{CG}=$ untreated animals $(\mathrm{n}=6) ; \mathrm{TG}=$ animals treated with Agaricus blazei $(\mathrm{n}=12)$.

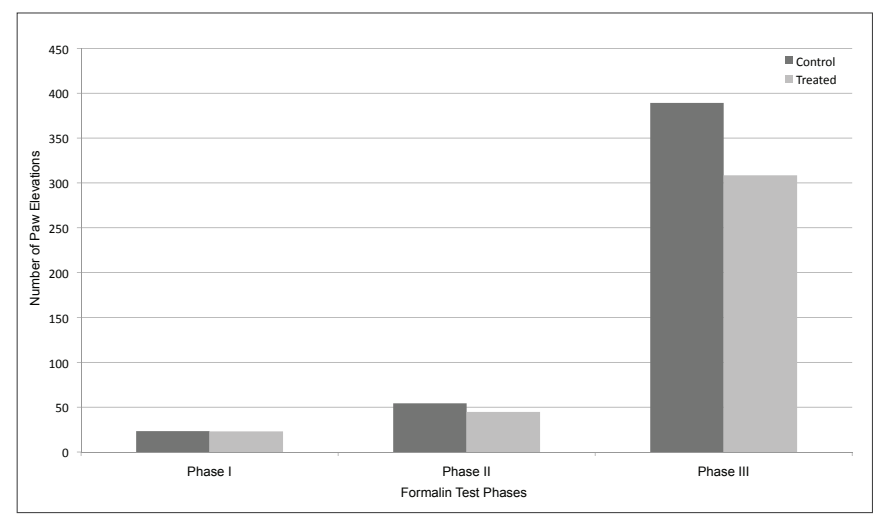

Graph 2 - Right paw elevation of male Wistar rats submitted to the modified formalin test, during the first five minutes (Phase I), from the sixth to the 21 st minute (Phase II) and from 21 st to 60 th minute (Phase III)).

$\mathrm{CG}=$ untreated animals $(\mathrm{n}=6)$; TG $=$ animals treated with Agaricus blazei $(\mathrm{n}=12) * \mathrm{p}<0.05$ as compared to $\mathrm{CG}$.

\section{DISCUSSION}

The formalin test, considered a reliable model of inflammatory chronic pain, is widely used to evaluate the action of analgesic drugs.

Subcutaneous formalin administration in rats' paw gen- erates stereotyped behaviors. Among such behaviors, paw elevation is a reliable parameter of painful behavior. Nociceptive response to formalin has two phases: there is a short initial period (phase I lasting from 5 to 10 minutes); then, after a short behavior remission period, phase II is started, consisting in a longer period (20 \pm 40 minutes) of sustained activity. In general, the initial response is attributed to the direct nociceptors activation, while phase II is associated to local endogen mediators release, which generate local inflammatory response, responsible for the sensitization of primary afferents and medullary neurons subsequent to the activation of nociceptors 5 .

The oral treatment with Agaricus blazei Murril for 15 days has not changed phase I or II of the formalin test as compared to control group. These results indicate that the treatment with the mushroom of the sun has not interfered with the activation of nociceptors or with the inhibitory pain descending pathway.

There has been decreased paw elevations in phase II of the formalin test in treated animals. This phase corresponds to pain induced by the acute inflammatory response and may have been obtained by the action of $A$. blazei on the inflammatory response.

The inflammatory response involves the activation of monocytes and macrophages, which secrete inflammatory response mediators, including nitric oxide (NO). Inducible nitric oxide synthase (iNOS) is one of the three enzymes producing NO. Increased NO secretion is involved in inflammatory processes and neuronal disorders ${ }^{6}$. Prostaglandins are potent proinflammatory agents, derived from arachidonic acid metabolism by cycloxygenase (COX). Cycloxygenase forms 1 and 2, have been widely studied. $\mathrm{COX}_{1}$ is constitutive and plays important role in cell functions modulation. $\mathrm{COX}_{2}$ is induced by several stimulations, including cytokines, during the inflammatory process $^{7}$. So, decreased NO production or COX activity, even by decreasing cytokines production, may contribute to the anti-inflammatory activity of Agaricus blazei, observed in this study.

Oral administration of $A$. blazei extracts inhibits nystatin-induced edema, production of nitric oxide, PGE2, IL- $1 \beta$ and TNF- $\alpha 6$. In addition, the administration of extracts has inhibited neutrophils migration ${ }^{8,9}$. A. bla$z e i$ anti-inflammatory action was attributed to polysaccharides present in the aqueous and alkaline extract, among them beta-glucans ${ }^{9}$. Anti-nociceptive and antiinflammatory actions of polysaccharides obtained from other Agaricus species have been reported in the litera- 
ture, among them the inhibition of cycloxygenase and nitric oxide synthase ${ }^{10}$.

In addition to the anti-inflammatory action, the 2-amino-3H-phenoxazine-3-ona compound, obtained from Agaricus bisporus Imbach, has inhibited nitric oxide and prostaglandin E2 production in macrophages after activation with LPS and gamma interferon, in addition to inhibiting cycloxygenase 1 and 2 activity. There has been increased interleukin 4 secretion and decreased interleukin 2 secretion, showing an immunemodulating action ${ }^{11}$.

Anti-allergic activity of $A$. blazei is related to the translation of lymphocytes into Th1 strain ${ }^{12}$.

Treatment with $A$. blazei for 15 days has decreased phase III of the formalin test. This decrease seems to be related to the anti-inflammatory and immune-modulating properties described for the mushroom of the sun. Regular consumption of the mushroom may be useful as complementary therapy in autoimmune and chronic inflammatory diseases, allergic syndromes and musculoskeletal pains.

\section{CONCLUSION}

As from the results obtained with the experiment, we concluded that Agaricus blazei acted on the nociceptive response and acute inflammation because rats treated with Agaricus had less paw movements during phase III, which is related to pain caused by mediators of the acute inflammatory process phase.

\section{REFERENCES}

1. Firenzuoli F, Gori L, Lombardo G. The Medicinal Mushroom Agaricus blazei Murrill: review of literature and pharmaco-toxicological problems. Evid Based Complement Alternat Med 2008;5(1)3-15.

2. Mattila P, Salo-Vaananen P, Konko K, et al. Basic composition and amino acid contents of mushrooms cultivat- ed in Finlands. J Agric Food Chem 2002;50(22):6419-22. 3. Mizuno TK. Agaricus blazei Murrill medicinal and dietary effects. Food Rev Int 1995;11(1):167-72

4. Takeda K, Okumura K. CAM and NK cells. Evid Based Complement Alternat Med 2004;(1):17-27

5. Sousa AM, Franco PA, Ashmawi HA, et al. Local effect of tramadol on formalin evoked flinching behavior in rats. Rev Bras Anestesiol 2008;58(4):371-9. 6. Dusse LMS, Vieira LM, Carvalho MG. Revisão sobre óxido nítrico. J Bras Patol Med Lab 2003;39(4):435-50. 7. Carvalho WA, Carvalho RD, Rios-Santos F. Specific cyclooxygenase-2 inhibitor analgesis: therapeutic advances. Rev Bras Anestesiol 2004;54(3):448-64.

8. Taveira VC, Reis MA, Silva MF, et. al. Efeitos do tratamento com Agaricus sylvaticus sobre a anemia e os níveis de proteína $\mathrm{C}$ reativa em animais com tumor sólido de Walker 256. Com Ciênc Saúde 2007;18(3):221-6.

9. Padilha MM, Avila AA, Sousa PJ, et al. Anti-inflammatory activity of aqueous and alkaline extracts from mushrooms (Agaricus blazei Murill). J Med Food 2009;12(2):359-64.

10. Guerra Dore CM, Azevedo TC, de Souza MC, et al. Antiinflammatory, antioxidant and cytotoxic actions of beta-glucan-rich extract from Geastrum saccatum mushroom. Int Immunopharmacol 2007;7(9):1160-9.

11. Kohno K, Miyake M, Sano O, et al. Anti-inflammatory and immunomodulatory properties of 2-amino-3H-phenoxazin-3-one. Biol Pharm Bull 2008;31(10):1938-45.

12. Bouike G, Nishitani Y, Shiomi H, et al. Oral treatment with extract of Agaricus blazei Murill enhanced Th1 response through intestinal epithelial cells and suppressed OVA-sensitized allergy in mice. Evid Based Complement Alternat Med 2011;1-11.

Presented in November 09, 2010.

Accepted for publication in March 02, 2011. 